\title{
Susceptibility of cariogenic microorganisms to phytoconstituents
}

\author{
G. L. S. Ferreira ${ }^{a}$, L. M. D. Bezerra ${ }^{b}$, I. L. A. Ribeiro ${ }^{c, d}$, R. C. D. Morais Júnior ${ }^{a}$ and \\ R. D. Castro ${ }^{a *}$ \\ aPrograma de Pós-graduação em Odontologia, Curso de Odontologia, Universidade Federal da Paraíba - UFPB, \\ CEP 58051-900, João Pessoa, PB, Brazil \\ 'Programa de Pós-graduação em Clínica Odontológica (Prótese Dentária), Faculdade de Odontologia de Piracicaba, \\ Universidade Estadual de Campinas - UNICAMP, CEP 13414-018, Piracicaba, SP, Brazil \\ 'Programa de Pós-graduação em Odontologia, Universidade Federal da Paraíba - UFPB, CEP 58051-900, \\ João Pessoa, PB, Brazil \\ dPrograma de Pós-graduação em Modelos de Decisão em Saúde, Universidade Federal da Paraíba - UFPB, \\ CEP 58051-900, João Pessoa, PB, Brazil \\ *e-mail: rcastro@ccs.ufpb.br
}

Received: January 5, 2017 - Accepted: May 2, 2017 - Distributed: November 30, 2018

\begin{abstract}
This study aimed to evaluate the in vitro antibacterial activity of the phytochemicals thymol, linalool, and citronellol against Streptococcus mutans, Streptococcus salivarius and Streptococcus oralis. Disk diffusion screening on solid medium and measurement of the diameter of the bacterial growth inhibition halos was the technique utilized. The Minimum Inhibitory Concentration (MIC) of the substances was determined using serial substance dilutions and microdilution technique in Brain Heart Infusion culture medium. After incubation for 24 hours in an oven at $37^{\circ} \mathrm{C}$, plate reading was completed and confirmed by visual method using 2,3,5 triphenyl tetrazolium chloride dye. The Minimum Bactericidal Concentration (MBC) was determined from MIC subcultures. Assays were performed in triplicate, and chlorhexidine was used as a positive control. The diameters in $\mathrm{mm}$ of the growth inhibition halos ranged between 7.3 and 10.7 for S. mutans, 7.3 and 10.0 for $S$. oralis, and 8.2 and 9.8 for $S$. salivarius. The MIC and MBC values obtained converged, ranging from maximum values in the presence of Linalool $(1,250.0 \mathrm{mg} / \mathrm{mL}, 2,500.0 \mathrm{mg} / \mathrm{mL}$ and 2,500.0 mg/mL, respectively, for S. mutans, S. oralis, and S. salivarius); and minimum values with Thymol $(312.5 \mu \mathrm{g} / \mathrm{ml}, 156.2 \mu \mathrm{g} / \mathrm{mL}$ and $156.2 \mu \mathrm{g} / \mathrm{ml}$, respectively for S. mutans, S. oralis, and S. salivarius). All the tested phytochemicals displayed antibacterial activity, thus representing substances with potential applications in preventing tooth decay.
\end{abstract}

Keywords: preventive dentistry, dental caries, citronellol, linalool, thymol.

\section{Susceptibilidade de microrganismos cariogênicos a fitoconstituintes}

\section{Resumo}

Este estudo objetivou avaliar a atividade antibacteriana in vitro dos fitoquímicos timol, linalol e citronelol sobre Streptococcus mutans, Streptococcus salivaris e Streptococcus oralis. Utilizou-se a técnica de discos de difusão em meio sólido e medição do diâmetro dos halos de inibição. A concentração inibitória mínima (CIM) das substâncias foi determinada utilizando diluições em série das substâncias e técnica de microdiluição em meio de cultura de Brain Heart Infusion. Após incubação durante 24 horas em estufa a $37^{\circ} \mathrm{C}$, a leitura da placa foi confirmada pelo método visual usando o corante 2,3,5 trifenil cloreto de tetrazólio. A concentração bactericida mínima (CBM) foi determinada a partir de subculturas de MIC. Os ensaios foram realizados em triplicata, e clorexidina foi usada como um controle positivo. Os diâmetros dos halos de inibição do crescimento variaram entre 7,3 e 10,7 por S. mutans, 7,3 e 10,0 por S. oralis, e 8,2 e 9,8 para S. salivaris. Os valores de CIM e CBM obtidos variaram de valores máximos na presença de linalol $(1.250,0 \mathrm{mg} / \mathrm{mL}, 2.500 .0 \mathrm{mg} / \mathrm{mL}$ e $2.500 .0 \mathrm{mg} / \mathrm{mL}$, respectivamente, para o $S$. mutans, S oralis e S. salivaris); a valores mínimos com timol $(312,5 \mu \mathrm{g} / \mathrm{ml}, 156,2 \mu \mathrm{g} / \mathrm{mL}$ e $156,2 \mu \mathrm{g} / \mathrm{ml}$, respectivamente para $S$. mutans, S. oralis e S. salivaris). Todos os fitoquímicos testados apresentaram atividade antibacteriana, representando, assim, substâncias com potencial de aplicações na prevenção da cárie dentária.

Palavras-chave: odontologia preventiva, cárie dental, citronelol, linalol, timol. 


\section{Introduction}

Dental caries and periodontal disease are the most common diseases of the human oral cavity, involving bacterial adhesion to both natural and restored tooth surfaces, and the development of biofilms (Venâncio et al., 2015). Tooth decay (carie) is a disease of tooth surface demineralization; caused by the acids produced by bacteria thru fermentation of dietary carbohydrates (Leites et al., 2006). Both biofilm control and the prevention of caries can be achieved through mechanical, chemical, and dietary processes. However, mechanical control is not always appropriate, especially in situations that limit its performance for instance; bedridden individuals admitted to intensive care, those with impaired motor coordination, orthodontic brace users, and people at high risk for the disease. These factors reinforce the importance antimicrobial substances used in compliment to promote oral health (Venâncio et al., 2015).

Streptococcus mutans is considered the main etiological agent of dental caries, and virulence factors, such as the composition of their cell surface and production of bacteriocins have been investigated in relation to its ability to cause cavities (Rodrigues et al., 2008). Other organisms such as Streptococcus oralis and Streptococcus salivarius participate in the initial formation of dental plaque, and also contribute to make the local environment adequate for S. mutans colonization, although for not being acidogenic or aciduric, they do not directly act in tooth enamel demineralization (Alves et al., 2010).

Currently, chlorhexidine gluconate (by its proven efficacy in chemical removal of cariogenic or periodontal-pathogenic biofilms), stands out among the antimicrobials used to fight oral microorganisms (Venâncio et al., 2015). However, given the limitations of this agent, (such as staining of the tooth surface, taste changes, and micro-biotic imbalances), other, naturally occurring agents have been investigated (Lawrence et al., 2008; Khan et al., 2009).

In this context, essential oils obtained from plants, products of natural origin, have a number of potential uses. Their constituents range from terpene hydrocarbons, simple and terpene alcohols, aldehydes, ketones, phenols, lactones, coumarins, to sulfur compounds. Yet the phytochemicals citronellol, linalool, and thymol (for having recognized antimicrobial activities) all stand out (Pereira et al., 2003; Priestley et al., 2003; Botelho et al., 2007).

From this perspective, the aim of this study is to evaluate the in vitro antibacterial activity of thymol, linalool, and citronellol, on cariogenic microorganisms.

\section{Material and Methods}

\subsection{Research locale and bacterial strains}

Microbiological tests were performed in the Oral Microbiology Laboratory, of the Center for Tropical Medicine, in the Health Sciences Center, at the Federal University of Paraíba, Paraíba, Brazil.

The bacterial strains studied were provided by the Oswaldo Cruz Foundation - Rio de Janeiro. The strains used were Streptococcus mutans (ATCC 25175), Streptococcus oralis (ATCC 10557), and Streptococcus salivarius (ATCC 7073). Bacterial suspensions for the studies were obtained from the specified colonies, dispersed in sterile saline in a glass tube, and stirred in a Vortex type tube shaker until obtaining a turbidity equivalent to the tube number 0.5 of the nephelometric McFarland scale.

Thymol, linalool, and citronellol were obtained, along with technical product information (Table 1), from Quinari ${ }^{\circledR}$, which produces and sells essential oils and derivatives on an industrial scale. The solutions were prepared using Tween 80 (1\%) (Vetec $^{\circledR}$, Rio de Janeiro, RJ, Brazil) and sterile distilled water at the time of susceptibility testing to achieve the desired concentrations.

A commercial formulation of chlorhexidine (Digluconate of Chlorexidine 2\% - FGM ${ }^{\circledR}$, Joinville, Santa Catarina, Brazil - Lot number 010609), was used as a positive control or standard drug.

\subsection{Cariogenic microorganism-phytochemical antibacterial activity screening}

The screening was performed by diffusion technique on solid media, as proposed by Bauer et al. (1966). In Petri dishes (CITOTEST ${ }^{\circledR}$ ) containing Muller Hinton Agar-(AMH) (Himedia $^{\circledR}$ ) culture medium were seeded $100 \mu \mathrm{L}$ inoculums of the S. mutans, S. oralis and S. salivarius bacterial strains.

Sterilized 6 millimeter $(\mathrm{mm})$ diameter absorbent paper disks were drenched with $30 \mu \mathrm{L}$ of thymol at $10.000 \mu \mathrm{g} / \mathrm{ml}$, and citronellol and linalool solution in their "pure" form (at $850,000 \mu \mathrm{g} / \mathrm{mL}$ ). The thymol solution was prepared using $70^{\circ}$ alcohol as solvent and the same was tested separately in order to rule out alcohol interference in the antibacterial activity of the phytoconstituent.

The discs were then arranged on the AMH agar. The plates were incubated in a bacteriological incubator for $24 \mathrm{~h}$ at $37^{\circ} \mathrm{C}$, and in the case of $S$. mutans in microaerophilic conditions. The study was performed in triplicate. The results were obtained by measuring the diameter of the bacterial growth inhibition halos in millimeters ( $\mathrm{mm}$ ) using a manual caliper, and the results were expressed as the arithmetic mean of the triplicate values.

\subsection{Determination of Minimum Inhibitory Concentration (MIC) - microdilution technique}

The determination of the MIC of the tested substances was carried out by microdilution technique. Initially, double concentrated $100 \mu \mathrm{L}$ of BHI (brain heart infusion) broth was distributed into the microdilution plates. Then $100 \mu \mathrm{L}$ of chlorhexidine and the phytochemicals in test were distributed, being serially diluted, with withdrawal of $100 \mu \mathrm{L}$ aliquots from the more concentrated cavities to the successor cavities. The initial concentration (Table 2) of each substance was determined by the successive trials method. At the

Table 1. Density $\mathrm{g} / \mathrm{mL}$ and lot of the phytochemicals thymol, linalool, and citronellol.

\begin{tabular}{ccc}
\hline Phytoconstituent & Density & Lot \\
\hline Thymol & 0.99 & 02235 \\
Linalool & 0.85 & 02235 \\
Citronellol & 0.85 & 02235 \\
\hline
\end{tabular}


mouths of each column were dispensed $10 \mu \mathrm{L}$ aliquots of bacterial inoculum of the tested strain at a concentration

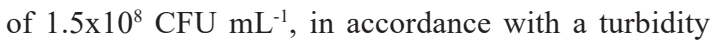
of 0.5 (nephelometric McFarland scale). In parallel, a viability control of the tested strains was conducted, and a sterility control of the culture medium.

Assays were performed in triplicate and the plates were incubated at $37^{\circ} \mathrm{C}$ for 24 hours. S. mutans was kept in microaerophilia. The MIC determination reading of substances against $S$. mutans, $S$. oralis and $S$. salivarius was carried out using a visual method. The formation of cell clumps "buttons" (or not) in the cavity plate background was taken into consideration. Thus, the lowest concentration of test product able to produce visible growth inhibition of the bacterial strain under microbiological assay (or MIC) was determined.

To confirm the presence of viable microorganisms for the non-inhibitory concentrations, we used TCT (2, 3, 5 triphenyl tetrazolium chloride) dye, at a volume of $10 \mu \mathrm{L}$, to detect the activity of dehydrogenase enzymes involved in the cellular respiration process, making it possible to distinguish the live samples, (red-stained), from the dead samples which retain their color (Deswal and Chand, 1997).

\subsection{Determination of Minimum Bactericidal Concentration - $M B C$}

After determining the MIC, the corresponding inhibitory concentration and the two immediately higher concentrations, as well as the positive controls were subcultured on Müller Hinton agar plates. After 24 hours of incubation at $37^{\circ} \mathrm{C}$, the readings of the MBCs were based on the growth of the controls, which was considered the lowest drug concentration that prevented visible growth in the subculture.

\section{Results}

The Table 3 expresses the mean in $\mathrm{mm}$, for the diameters of bacterial growth inhibition zones for pure citronellol and linalool, of thymol solution at $10.000 \mu \mathrm{g} / \mathrm{mL}$, of $2 \%$ chlorhexidine, and alcohol $70^{\circ}$ against the tested microorganisms. All tested phytochemicals showed an antibacterial effect, with larger microbial growth inhibition zones for citronellol being observed on $S$. mutans $(10.7 \pm 1.15 \mathrm{~mm})$ and $S$. salivarius $(9.8 \pm 1.44 \mathrm{~mm})$.

The Table 4 presents the results of MIC and MBC, in $\mu \mathrm{g} / \mathrm{mL}$, of the substances against $S$. mutans, $S$. oralis and $S$ salivarius. Tymol exhibited lower inhibitory concentrations against microorganisms tested, with MIC of $156.2 \mu \mathrm{g} / \mathrm{mL}$ for $S$. oralis e $S$. salivarius e $312,5 \mu \mathrm{g} / \mathrm{mL}$ for $S$. mutans.

Table 2. Initial concentrations of the phytochemicals Thymol, and Linalool Citronellol with the positive control chlorhexidine for determination of minimum inhibitory.concentration (MIC).

\begin{tabular}{lcccc}
\hline \multicolumn{1}{c}{ Bacterial Strains } & Thymol & Linalool & Citronellol & Chlorexidine \\
\hline Streptococcus mutans & $2.500 \mu \mathrm{g} / \mathrm{mL}$ & $40.000 \mu \mathrm{g} / \mathrm{mL}$ & $80.000 \mu \mathrm{g} / \mathrm{mL}$ & $1.200 \mu \mathrm{g} / \mathrm{mL}$ \\
Streptococcus oralis & $2.500 \mu \mathrm{g} / \mathrm{mL}$ & $40.000 \mu \mathrm{g} / \mathrm{mL}$ & $20.000 \mu \mathrm{g} / \mathrm{mL}$ & $300 \mu \mathrm{g} / \mathrm{mL}$ \\
Streptococcus salivarius & $2.500 \mu \mathrm{g} / \mathrm{mL}$ & $40.000 \mu \mathrm{g} / \mathrm{mL}$ & $20.000 \mu \mathrm{g} / \mathrm{mL}$ & $300 \mu \mathrm{g} / \mathrm{mL}$ \\
\hline
\end{tabular}

Table 3. Average in mm (mean, standard deviation), of the bacterial growth inhibition zone diameters for (undiluted) linalool, citronellol, $10.000 \mathrm{ug} / \mathrm{mL}$ thymol solution, $2 \%$ chlorhexidine and alcohol $70^{\circ}$ against Streptococcus mutans, Streptococcus oralis and Streptococcus salivarius.

\begin{tabular}{cccc}
\hline & S. mutans & S. oralis & S. salivarius \\
\hline Linalool & $8 \pm 0.0$ & $9 \pm 1.0$ & $8.2 \pm 0.2$ \\
Citronellol & $10.7 \pm 1.1$ & $10 \pm 1.0$ & $9.8 \pm 1.4$ \\
Thymol & $7.3 \pm 0.2$ & $7.3 \pm 0.7$ & $8.3 \pm 0.1$ \\
Chlorexidine 2\% & $17 \pm 0.5$ & $16.8 \pm 0.7$ & $19.7 \pm 0.5$ \\
Alcohol 70 $^{\circ}$ & 0 & 0 & 0 \\
\hline
\end{tabular}

Table 4. Minimum inhibitory concentration (MIC) and Minimum Bactericidal Concentration (MBC) values of the phytochemicals thymol, citronellol, linalool, and chlorhexidine against Streptococcus mutans, Streptococcus salivarius and Streptococcus oralis.

\begin{tabular}{cccccc}
\hline Microorganism & & $\begin{array}{c}\text { Thymol } \\
(\boldsymbol{\mu g} / \mathbf{m L})\end{array}$ & $\begin{array}{c}\text { Citronellol } \\
(\boldsymbol{\mu g} / \mathbf{m L})\end{array}$ & $\begin{array}{c}\text { Linalool } \\
(\boldsymbol{\mu g} / \mathbf{m L})\end{array}$ & $\begin{array}{c}\text { Chlorexidina } \\
(\boldsymbol{\mu g} / \mathbf{m L})\end{array}$ \\
\hline Streptococcus mutans & MIC & 312.5 & 625.0 & 1250.0 & 9.4 \\
Streptococcus oralis & MBC & 312.5 & 625.0 & 1250.0 & 9.4 \\
& MIC & 156.2 & 625.0 & 2500.0 & 4.7 \\
Streptococcus salivarius & MBC & 156.2 & 625.0 & 2500.0 & 4.7 \\
& MIC & 156.2 & 625.0 & 2500.0 & 4.7 \\
& MBC & 156.2 & 625.0 & 2500.0 & 4.7 \\
\hline
\end{tabular}




\section{Discussion}

The development of natural product applications for the prevention and treatment of diseases, including the field of dentistry, is promising. Considering the need to expand our therapeutic arsenal and the limitations of the available synthetics, scientific research should be undertaken with environmental sustainability in mind (Albuquerque and Hanazaki, 2006). Research in herbal medicine as applied to dentistry is relevant not only because it presents more cost-effective solutions to the population, but also for the ease and availability with which these substances are found (Freires et al., 2010).

According Margis et al. (1998), it is important that their use be not restricted exclusively to folk medicine, but also that through scientific knowledge, they become acceptable to health professionals. Many plant species, their extracts, and isolated phytochemicals have been investigated for antimicrobial action against oral microorganisms (Harris, 2002; Reis et al., 2014; Freires et al., 2015).

From among the many substances obtained from medicinal plants, linalool, citronellol, and thymol have all been cited in the literature for their antimicrobial activity (Robledo et al., 2005).

Natural products are considered potent inhibitors of microbial activity when their MIC values are equal to or lower than $500 \mu \mathrm{g} / \mathrm{mL}$ (Tobaldini-Valerio et al., 2016 ). Constituents isolated from natural products with MIC range of $101-500 \mu \mathrm{g} / \mathrm{mL}$ are considered with strong activity, and moderate activity when exhibit MIC range of 501-1000 $\mu \mathrm{g} / \mathrm{mL}$ (Freires et al., 2015). Considering these parameters, the results of this study indicate that thymol and citronellol exhibited strong and moderate activity, respectively.

Alviano et al. (2005) evaluated the antimicrobial activity of purified linalool extracted by hydro-distillation from the leaves of Croton cajucara. The MIC was determined against microorganisms isolated from fixed orthodontic appliance users of saliva samples and reference strains. Among the tested strains of Lactobacillus casei (ATCC 4646), Streptococcus sobrinus (ATCC 27609), Streptococcus mutans (ATCC 25175), Porphyromonas gingivalis (ATCC 43146), Staphylococcus aureus (ATCC 49456) and Candida albicans (ATCC 51501), microorganism growth was inhibited by purified linalool (MIC $=0.7 \mathrm{~g} / \mathrm{mL}$ ) only in Candida albicans. In contrast, the essential oil of C. cajucara itself tested at different concentrations inhibited growth of all the microorganisms.

Our results differ from the aforementioned study since linalool showed antibacterial activity against $S$. mutans, $S$. salivarius and $S$. oralis in all the tests. Differences in the initial concentration of the substance may explain the difference in the results, since the MIC values obtained in this study vary from 1250 to $2500 \mu \mathrm{g} / \mathrm{mL}$, and the MIC of linalool against $C$. albicans determined by the authors at $0,7 \mu \mathrm{g} / \mathrm{ml}$, corresponds to a much lower value.

Park et al. (2012) evaluated the antimicrobial activity of linalool against cariogenic and periodontal bacteria by microdilution technique, determining the Minimum Inhibitory Concentration (MIC) and Minimum Bactericidal Concentration (MBC). The MIC and MBC values obtained from the reference strain of $S$. mutans (ATCC 25175T) were $1600 \mu \mathrm{g} / \mathrm{ml}$ and $3200 \mu \mathrm{g} / \mathrm{ml}$, respectively, and $1600 \mu \mathrm{g} / \mathrm{ml}$ and $1600 \mu \mathrm{g} / \mathrm{ml}$ respectively for $S$. sobrinus (ATCC 33478T). Values of MIC lower than $100 \mu \mathrm{g} / \mathrm{ml}$, were found for the clinical strains of $S$. mutans tested.

Data from this study corroborate the findings of Park et al. (2012); the concentrations found in the linalool MIC tests against $S$. mutans are quite similar to the $1250 \mu \mathrm{g} / \mathrm{mL}$ value. However, in the cited research there were differences between the MIC and MBC values. In this study, the same concentration that inhibited $S$. mutans bacterial growth was able to cause microorganism death.

The literature reports both insecticide and bacteriostatic activity for citronellol (Oliveira-Filho et al., 2017; Robledo et al., 2005; Alviano et al., 2005; Park et al., 2012). Haida et al. (2007) suggest that the essential oil obtained from the plant Cymbopogon citratus has citronellol as one of its chemical components, having antibacterial activity against some 20 bacterial species. In a study by Schuck et al. (2001), the authors found that the oil of $C$. citratus presents antimicrobial activity against various microorganisms, among which may be mentioned Staphylococcus aureus. Our results concerning the antibacterial activity of citronellol are in agreement with the studies cited, having averaged halo diameters of $10.7 \mathrm{~mm}$ for $S$. mutans, $10.0 \mathrm{~mm}$ for $S$. oralis, and $9.8 \mathrm{~mm}$ for $S$. salivarius.

Studies report that thymol has anti-inflammatory, antioxidant, antimicrobial, antiseptic and healing properties, its main therapeutic application is for use in dental preparations, as a bactericide (Priestley et al., 2003; Robledo et al., 2005). It is poorly soluble in water at neutral $\mathrm{pH}$, but very soluble in alcohol and other organic solvents (Park et al., 2012), which justifies the use of alcohol as a solvent and as the negative control test in this study. Alcohol $70^{\circ}$ did not inhibit bacterial growth, demonstrating that the antimicrobial activity of the thymol solution was not affected by using alcohol as solvent. As in a previous study (Julião et al., 2003), the phytoconstituent thymol displayed the lowest minimum inhibitory and minimum bactericidal concentrations.

Botelho et al. (2007), from the analysis of the phytochemical composition of Lippia sidoides Cham (pepper rosemary), isolated thymol as the major compound $(56.7 \%)$. They evaluated the antimicrobial activity of this phytoconstituent using diffusion technique in a solid medium and determination of MIC and MBC using microdilution technique. The microorganisms included strains of $S$. mutans and $S$. salivarius. In the diffusion test on solid medium, thymol (at $50 \mathrm{mg} / \mathrm{mL}$ ) promoted bacterial growth inhibition zones corresponding to 7.8 and $7.7 \mathrm{~mm}$ respectively for the aforementioned strains. The values of MIC and MBC corresponded to 5.0 and $10.0 \mathrm{mg} / \mathrm{mL}$ respectively for both strains. 
These results corroborate our findings, and confirm the antibacterial activity of thymol against $S$. mutans and $S$. salivarius. The differences between the studies are found in the concentration values for MIC and MBC. The strains tested, the manner of solution preparation, and methodological differences may explain these differences. Standardization of methodologies would be a way to reduce discrepancies between different studies, which would facilitate comparisons between results obtained by different authors.

For all the substances tested, the MBC was the same as the MIC. This means that the substances tested at these concentrations, have a bactericidal effect on the microorganisms studied.

Phytochemicals are small, organic, generally hydrophobic biomolecules known as natural antibiotics which possibly exert their antimicrobial activity thru rupture of the cytoplasmic membrane (Park et al., 2012). The antibacterial activity evidenced by the substances used in this study, (considering their molecular structures), suggests involvement of the bacterial cell membrane. Due to their high volatility and lipophilicity, they readily penetrate the cell membrane and exert their biological effects (Ordóñez et al., 2004), increasing its permeability; blocking further membrane synthesis; inhibiting cell growth and respiration, and leading to cell death (Haida et al., 2007).

It is emphasized that this study represents an initial assessment to determine the antibacterial activity of these phytochemicals. It is necessary to develop further pre-clinical trials, including microbial death curve assessments, and studies on possible mechanisms of action and toxicological properties.

The present study verified that the thymol, linalool, and citronellol revealed in vitro antibacterial activity, being bacteriostatic and bactericidal against $S$. mutans, S. oralis and S. salivarius.

Among the evaluated phytochemicals, thymol stand outs for its lower MIC and MBC values; as does citronellol for its greater bacterial growth inhibition halos. They represent potential candidates for use in products for the prevention and treatment of dental caries.

\section{Acknowledgements}

This study was carried out at in the Laboratory of Oral Microbiology - Tropical Medicine Center (NUMETROP) of Center for Health Sciences, Federal University of Paraiba, Paraiba, Brazil. The strains were generously provided by the FIOCRUZ (Oswaldo Cruz Foundation).

\section{References}

ALBUQUERQUE, U.P. and HANAZAKI, N., 2006. As pesquisas etnodirigidas na descoberta de novos fármacos de interesse médico e farmacêutico: fragilidades e pespectivas. Revista Brasileira de Farmacognosia, vol. 16, no. 1, pp. 678-689. http://dx.doi. org/10.1590/S0102-695X2006000500015.
ALVES, T.M.S., SILVA, C.A., SILVA, N.B., MEDEIROS, E.B. and VALENÇA, A.M.G., 2010. Atividade antimicrobiana de produtos fluoretados sobre bactérias formadoras do biofilme dentário: estudo in vitro. Pesquisa Brasileira em Odontopediatria e Clinica Integrada, vol. 10, no. 2, pp. 209-216. http://dx.doi.or $\mathrm{g} / 10.4034 / 1519.0501 .2010 .0102 .0013$.

ALVIANO, W.S., MENDONCA-FILHO, R.R., ALVIANO, D.S., BIZZO, H.R., SOUTO-PADRON, T., RODRIGUES, M.L., BOLOGNESE, A.M., ALVIANO, C.S. and SOUZA, M.M.G., 2005. Antimicrobial activity of Croton cajucara Benth linalool-rich essential oil on artificial biofilms and planktonic microorganisms. Oral Microbiology and Immunology, vol. 20, no. 2, pp. 101-105. PMid:15720570. http://dx.doi.org/10.1111/j.1399302X.2004.00201.x.

BAUER, A.W., KIRBY, W.M., SHERRIS, J.C. and TURCK, M., 1966. Antibiotic susceptibility testing by a standardized single disk method. American Journal of Clinical Pathology, vol. 45, no. 4, pp. 493-496. PMid:5325707.

BOTELHO, M.A., NOGUEIRA, N.A.P., BASTOS, G.M., FONSECA, S.G.C., LEMOS, T.L.G., MATOS, F.J.A., MONTENEGRO, D., HEUKELBACH, J., RAO, V.S. and BRITO, G.A.C., 2007. Antimicrobial activity of the essential oil from Lippia sidoides, carvacrol and thymol against oral pathogens. Brazilian Journal of Medical and Biological Research, vol. 40, no. 3, pp. 349-356. PMid:17334532. http://dx.doi.org/10.1590/ S0100-879X2007000300010.

DESWAL, D.P. and CHAND, U., 1997 [viewed 5 January 2017]. Standardization of the tetrazolium test for viability estimation in ricebean (Vigna umbellata (Thunb.) Ohwi \& ohashi) seeds. Seed Science and Technology [online], vol. 25, no. 3, pp. 409417. Available from: http://cat.inist.fr/?aModele=afficheN\&cp sidt $=2141270$

FREIRES, I.A., ALVES, L.A., JOVITO, V.C., ALMEIDA, L.F.D., CASTRO, R.D. and PADILHA, W.W.N., 2010 [viewed 5 January 2017]. Atividades antibacteriana e antiaderente in vitro de tinturas de Schinus terebinthinfolius (Aroeira) e Solidago microglossa (Arnica) frente a bactérias formadoras do biofilme dentário. Odontologia Clínico-Científica [online], vol. 9, no. 2, pp. 139-143. Available from: http://revodonto.bvsalud.org/scielo. php?script $=$ sci_arttext\&pid=S1677-38882010000200010\&lng= pt\&nrm=iso

FREIRES, I.A., DENNY, C., BENSO, B., ALENCAR, S.M. and ROSALEN, P.L., 2015. Antibacterial activity of essential oils and their isolated constituents against cariogenic bacteria: a systematic review. Molecules, vol. 20, no. 4, pp. 7329-7358. PMid:25911964. http://dx.doi.org/10.3390/molecules20047329.

HAIDA, K.S., PARZIANELLO, L., WERNER, S., GARCIA, D.R. and INÁCIO, C.V., 2007. Avaliação in vitro da atividade antimicrobiana de oito espécies de plantas medicinais. Arquivos de Ciências da Saúde da UNIPAR, vol. 11, no. 3, pp. 185-192.

HARRIS, R., 2002. Progress with superficial mycoses using essential oils. International Journal of Aromatherapy, vol. 12, no. 2, pp. 83-91. http://dx.doi.org/10.1016/S0962-4562(02)00032-2.

JULIÃO, L.S., TAVARES, E.S., LAGE, C.L.S. and LEITÃO, S.G., 2003. Cromatografia em camada fina de extratos de três quimiotipos de Lippia alba (Mill) N.E.Br. (Erva-Cidreira). Revista Brasileira de Farmacognosia, vol. 13, no. 1, pp. 36-38. http:// dx.doi.org/10.1590/S0102-695X2003000300014.

KHAN, M.R., RIZVI, W., KHAN, G.N., KHAN, R.A. and SHAHEEN, S., 2009. Carbon tetrachloride nduced nephrotoxicity 
in rats: protective role of Digera muricata. Journal of Ethnopharmacology, vol. 122, no. 1, pp. 91-99. PMid:19118616. http://dx.doi.org/10.1016/j.jep.2008.12.006.

LAWRENCE, J.R., ZHU, B., SWERHONE, G.D., TOPP, E., ROY, J., WASSENAAR, L.I., REMA, T. and KORBER, D.R., 2008. Community-level assessment of the effects of the broadspectrum antimicrobial chlorhexidine on the outcome of river microbial biofilm development. Applied and Environmental Microbiology, vol. 74, no. 11, pp. 3541-3550. PMid:18378652. http://dx.doi.org/10.1128/AEM.02879-07.

LEITES, A.C.B.R., PINTO, M.B. and SOUSA, E.R.S., 2006 [viewed 5 January 2017]. Aspectos microbiológicos da cárie dental. Salusvita [online], vol. 25, no. 2, pp. 239-252. Available from: https://secure.usc.br/static/biblioteca/salusvita/salusvita v25_n2_2006_art_09.pdf

MARGIS, R., REIS, E.M. and VILLERET, V., 1998. Structural and phylogenetic relationships among plant and animal cystatins. Archives of Biochemistry and Biophysics, vol. 359, no. 1, pp. 24-30. PMid:9799556. http://dx.doi.org/10.1006/abbi.1998.0875.

OLIVEIRA FILHO, A.A., OLIVEIRA, H.M.B.F., MEDEIROS, C.I.S., PESSÔA, H.D.L.F., SIQUEIRA JÚNIOR, J.P. and OLIVEIRA, E.L., 2017. Antifungal effect of 7-hydroxycitronellal against C. Tropicalis strains: an in vitro approach. Bioscience Journal, vol. 33, no. 1, pp. 204-208. http://dx.doi.org/10.14393/ BJ-v33n1a2017-33851.

ORDÓÑEZ, M.G., JORGE, M.R., SIMÓN, G.G. and RANGEL, C.L., 2004 [viewed 5 January 2017]. Actividad antimicrobiana Del aceite esencial y crema de Cymbopogon citratus (DC). Stapf. Revista Cubana de Plantas Medicinales [online], vol. 9, no. 2. Available from: http://bvs.sld.cu/revistas/pla/vol9 2 2 $04 /$ pla05204.htm

PARK, S.N., LIM, Y.K., FREIRE, M.O., CHO, E., JIN, D. and KOOK, J., 2012. Antimicrobial effect of linalool and $\alpha$-terpineol against periodontopathic and cariogenic bacteria. Anaerobe, vol. 18, no. 3, pp. 369-372. PMid:22537719. http://dx.doi.org/10.1016/j. anaerobe.2012.04.001.

PEREIRA, R.C., DAMA, B.A.P., TEIXEIRA, V.L. and YONESHIGUE-VALENTIN, T., 2003. Ecological roles of natural products of the Brazilian red seaweed Laurencia obtusa. Brazilian Journal of Biology $=$ Revista Brasileira de Biologia, vol. 63, no. 4, pp. 665-672. PMid:15029377. http://dx.doi.org/10.1590/ S1519-69842003000400013.
PRIESTLEY, C.M., WILLIAMSON, E.M., WAFFORD, K.A. and SATTELLE, D.B., 2003. Thymol, a constituent of thyme essential oil, is a positive allosteric modulator of human GABAA receptors and a homo-oligomeric GABA receptor from Drosophila melanogaster. British Journal of Pharmacology, vol. 140, no. 8, pp. 1363-1372. PMid:14623762. http://dx.doi.org/10.1038/ sj.bjp. 0705542 .

REIS, L.B.M., FARIAS, A.L., BOLLELLA, A.P., SILVA, H.K.M., CANUTO, M.I.C., ZAMBELLI, J.C. and FREIRE, M.D.C.M., 2014. Conhecimentos, atitudes e práticas de Cirurgiões-Dentistas de Anápolis-GO sobre a fitoterapia em odontologia. Revista de Odontologia da UNESP, vol. 43, no. 5, pp. 319-325. http://dx.doi. org/10.1590/rou.2014.051.

ROBLEDO, S., OSORIO, E., MUÑOZ, D., JARAMILLO, L.M., RETRESPO, A., ARANGO, G. and VÉLEZ, I., 2005. In vitro and in vivo cytotoxicities and antileishmanial activities of thymol and hemisynthetic derivatives. Antimicrobial Agents and Chemotherapy, vol. 49, no. 4, pp. 1652-1655. PMid:15793164. http://dx.doi.org/10.1128/AAC.49.4.1652-1655.2005.

RODRIGUES, M.R., MACIEL, S.M., FERREIRA, F.B.A., PIOVEZAN, A., PIERALISI, F.J.S. and POLI-FREDERICO, R.C., 2008 [viewed 5 January 2017]. Análise do sorotipo e dos genes para mutacinas em Streptococcus mutans isolados de préescolares com diferentes experiências de cárie. Brazilian Dental Science [online], vol. 11, no. 4, pp. 40-46. Available from: http:// ojs.fosjc.unesp.br/index.php/cob/article/view/665

SCHUCK, V.J.A., FRATINI, M., RAUBER, C.S., HENRIQUES, A. and SHAPOVAL, E.E., 2001 [viewed 5 January 2017]. Evaluation of the antimicrobial activity of Cymbopogon citratus. Brazilian Journal of Pharmaceutical Sciences [online], vol. 37, no. 1, pp. 45-49. Available from: http://www.scielo.br/scielo. php?script $=$ sci_issues\&pid $=1984-8250 \& \operatorname{lng}=\mathrm{en} \& \mathrm{nrm}=$ iso

TOBALDINI-VALERIO, F.K., BONFIM-MENDONÇA, P.S., ROSSETO, H.C., BRUSCHI, M.L., HENRIQUES, M., NEGRI, M., SILVA, S. and SVIDZINSKI, T.I., 2016. Propolis: a potential natural product to fight Candida species infections. Future Microbiology, vol. 11, no. 8, pp. 1035-1046. PMid:27501739. http://dx.doi.org/10.2217/fmb-2015-0016.

VENÂNCIO, G.N., RODRIGUES, I.C., SOUZA, T.P., MARREIRO, R.O., BANDEIRA, M.F.C.L. and CONDE, N.C.O., 2015. Herbal mouthwash based on Libidibia ferrea: microbiological control, sensory characteristics, sedimentation, $\mathrm{pH}$ and density. Revista de Odontologia da UNESP, vol. 44, no. 2, pp. 118-124. http:// dx.doi.org/10.1590/1807-2577.1064. 